\title{
KOOPERATIF MODEL TGT PADA PEMBELAJARAN BAHASA INDONESIA
}

\author{
N. RANI SUNINGSIH \\ SMPN 1 Plered Purwakarta \\ e-mail: nranisuningsih@gmail.com
}

\begin{abstract}
ABSTRAK
Penelitian ini dilaksanakan di Kelas IX H SMPN 1 Plered - Purwakarta. Penelitian ini bertujuan untuk mendeskripsikan proses peningkatan prestasi belajar siswa dalam pembelajaran bahasa Indonesia pada kelas IX H SMPN 1 Plered - Purwakarta dengan menggunakan kooperatif model TGT, mulai dari proses perencanaan, pelaksanaan dan evaluasi. Selain itu, metode penelitian ini menggunakan pendekatan deskriptif kualitatif dan tindakan kelas. Untuk mengetahui peningkatan prestasi belajar siswa dalam pembelajaran bahasa Indonesia, penelitian ini dilakukan dalam tiga siklus, Penelitian ini diawali dengan pre-test dan diakhiri dengan posttest. Hasil penelitian menunjukkan bahwa dengan menggunakan menggunakan kooperatif model TGT, skor perbandingan untuk pre-test dan post-test meningkat secara signifikan. Hal ini terlihat dari hasil analis didapatkan kalau prestasi belajar siswa hadapi kenaikan dari siklus I hingga siklus III ialah, siklus I (60, 71\%), siklus II (75, 00\%), siklus III (89, 29\%).
\end{abstract}

Kata Kunci: Pembelajaran Bahasa Indonesia, Kooperatif model TGT

\section{ABSTRACT}

This research was conducted in Class IX H SMPN 1 Plered - Purwakarta. This study aims to describe the process of improving student achievement in learning Indonesian in class IX H of SMPN 1 Plered - Purwakarta by using the TGT cooperative model, starting from the planning, implementation and evaluation processes. In addition, this study uses a qualitative descriptive approach and classroom action. To find out the increase in student achievement in learning Indonesian, this research was conducted in three cycles. This study begins with a pre-test and ends with a post-test. The results showed that by using the cooperative TGT model, the comparison scores for pre-test and post-test increased significantly. This can be seen from the results of the analysis that students' learning achievement faces an increase from cycle I to cycle III, namely, cycle I $(60,71 \%)$, cycle II $(75.00 \%)$, cycle III $(89,29 \%)$.

Keywords: Indonesian Language Learning, Cooperative TGT model

\section{PENDAHULUAN}

Bahasa Indonesia ialah sesuatu bahan kajian yang mempunyai objek bahasan yang sangat luas serta dibentuk lewat proses penalaran yang dinamis, sehingga keterkaitan antar konsep dalam Bahasa Indonesia bertabiat uraian. Dalam pendidikan Bahasa Indonesia supaya gampang dipahami oleh siswa, proses penalaran deduktif buat memantapkan uraian yang telah dipunyai oleh siswa. Tujuan pendidikan Bahasa Indonesia merupakan melatih metode berfikir secara sistematis, logis, kritis, kreatif serta tidak berubah- ubah.

Langkah- langkah tersebut membutuhkan partisipasi aktif dari siswa. Buat itu butuh terdapat tata cara pendidikan yang mengaitkan siswa secara langsung dalam pendidikan. Ada pula tata cara yang diartikan merupakan tata cara pembelajaan kooperatif. Pendidikan kooperatif merupakan sesuatu pengajaran yang mengaitkan siswa bekerja dalam kelompokkelompok buat menetapkan tujuan bersama. Felder, (1994: 2).

Pendidikan kooperatif lebih menekankan interaksi antar siswa. Dari mari siswa hendak melaksanakan komunikasi aktif dengan sesama temannya. Dengan komunikasi tersebut diharapkan siswa bisa memahami modul pelajaran dengan gampang sebab siswa lebih gampang menguasai uraian dari kawannya dibandingkan uraian dari guru sebab taraf pengetahuan dan pemikiran mereka lebih sejalan serta proporsional”. (Sulaiman dalam Wahyuni 2001: 2). Riset pula menampilkan kalau pendidikan kooperatif mempunyai akibat yang amat positif terhadap siswa yang rendah hasil belajarnya. (Nur, 1996: 2). 
Pete Tschumi dari Universitas Arkansas Little Rock memperkenalkan sesuatu ilmu pengetahuan pengantar pelajaran pc sepanjang $3 \mathrm{kali}$, yang awal siswa bekerja secara orang, serta 2 kali secara kelompok. Dalam kelas awal cuma 36\% siswa yang menemukan nilai C ataupun lebih baik, serta dalam kelas yang bekerja secara kooperatif terdapat $58 \%$ serta $65 \%$ siswa yang menemukan nilai C ataupun lebih baik (Felder, 1994: 14). Bersumber pada paparan tersebut di atas hingga periset mau berupaya melaksanakan riset dengan judul "Meningkatkan Prestasi Belajar Bahasa Indonesia Siswa Kelas IX H SMPN 1 Plered - Purwakarta Tahun Pelajaran 2020/ 2021 Dengan Model Pendidikan TGT".

Merujuk pada uraian latar belakang di atas, dapat dikaji ada beberapa permasalahan yang lirumuskan sebagai berikut: (1) Apakah pembelajaran kooperatif model TGT berpengaruh terhadap hasil belajar Bahasa Indonesia siswa Kelas IX H SMPN 1 Plered Purwakarta Tahun Pelajaran 2020/2021? (2) Seberapa tinggi tingkat penguasaan materi pelajaran Bahasa Indonesia dengan diterapkannya metode pembelajaran kooperatif model TGT pada siswa Kelas IX H SMPN 1 Plered - Purwakarta Tahun Pelajaran 2020/2021?

Adapun tujuan dilaksanakan penelitian ini adalah:Untuk (1) Mengungkap pengaruh pembelajaran kooperatif model TGT terhadap hasil belajar Bahasa Indonesia siswa Kelas IX H SMPN 1 Plered - Purwakarta Tahun Pelajaran 2020/2021? (2) Ingin mengetahui seberapa jauh pemahaman dan penguasaan mata pelajaran Bahasa Indonesia setelah diterapkannya pembelajaran kooperatif model TGT pada siswa Kelas IX H SMPN 1 Plered - Purwakarta Tahun Pelajaran 2020/2021?

\section{METODE PENELITIAN}

Penelitian ini merupakan penelitian tindakan (action research), karena penelitian dilakukan untuk memecahkan masalah pembelajaran di kelas. Penelitian ini juga termasuk penelitian deskriptif, sebab menggambarkan bagaimana suatu teknik pembelajaran diterapkan dan bagaimana hasil yang diinginkan dapat dicapai.

Menurut Oja dan Sumarjan (dalam Titik Sugiarti, 1997: 8) mengelompokkan penelitian tindakan menjadi empat macam yaitu, (a) guru sebagai peneliti, (b) penelitian tindakan kolaboratif; (c) simultan terintegratif; (d) administrasi sosial eksperimental.

Dalam penelitian tindakan ini menggunakan bentuk guru sebagai peneliti, penanggung jawab penuh penelitian ini adalah guru. Tujuan utama dari penelitian tindakan ini adalah untuk meningkatkan hasil pembelajaran di kelas dimana guru secara penuh terlibat dalam penelitian mulai dari perencanaan, tindakan, pengamatan, dan refleksi.

Dalam penelitian ini peneliti tidak bekerjasama dengan siapapun, kehadiran peneliti sebagai guru di kelas sebagai pengajar tetap dan dilakukan seperti biasa, sehingga siswa tidak tahu kalau diteliti. Dengan cara ini diharapkan didapatkan data yang seobjektif mungkin demi kevalidan data yang diperlukan.

Tempat penelitian adalah tempat yang digunakan dalam melakukan penelitian untuk memperoleh data yang diinginkan. Penelitian ini bertempat di SMPN 1 Plered - Purwakarta, subyek penelitian adalah siswa-siswi Kelas IX H SMPN 1 Plered - Purwakarta tahun pelajaran 2020/2021 pada pokok bahasan pidato persuasive.

Waktu penelitian adalah waktu berlangsungnya penelitian atau saat penelitian ini dilangsungkan. Penelitian ini dilaksanakan pada bulan November semester ganjil tahun pelajaran 2020/2021.

Penelitian ini menggunakan Penelitian Tindakan Kelas (PTK). Menurut Tim Pelatih Proyek PGSM, PTK adalah suatu bentuk kajian yang bersifat reflektif oleh pelaku tindakan yang dilakukan untuk meningkatkan kemantapan rasional dari tindakan mereka dalam melaksanakan tugas, memperdalam pemahaman terhadap tindakan-tindakan yang dilakukan itu, serta memperbaiki kondisi dimana praktek pembelajaran tersebut dilakukan (dalam Mukhlis, 2000: 3). 
Sedangkah menurut Mukhlis (2000: 5) PTK adalah suatu bentuk kajian yang bersifat sistematis reflektif oleh pelaku tindakan untuk memperbaiki kondisi pembelajaran yang dilakukan.

Adapun tujuan utama dari PTK adalah untuk memperbaiki/meningkatkan pratek pembelajaran secara berkesinambungan, sedangkan tujuan penyertaannya adalah menumbuhkan budaya meneliti di kalangan guru (Mukhlis, 2000: 5).

Sesuai dengan jenis penelitian yang dipilih, yaitu penelitian tindakan, maka penelitian ini menggunakan model penelitian tindakan dari Kemmis dan Taggart (dalam Sugiarti, 1997: 6), yaitu berbentuk spiral dari siklus yang satu ke siklus yang berikutnya. Setiap siklus meliputi planning (rencana), action (tindakan), observation (pengamatan), dan reflection (refleksi). Langkah pada siklus berikutnya adalah perncanaan yang sudah direvisi, tindakan, pengamatan, dan refleksi. Sebelum masuk pada siklus 1 dilakukan tindakan pendahuluan yang berupa identifikasi permasalahan. Siklus spiral dari tahap-tahap penelitian tindakan kelas dapat dilihat pada gambar berikut.

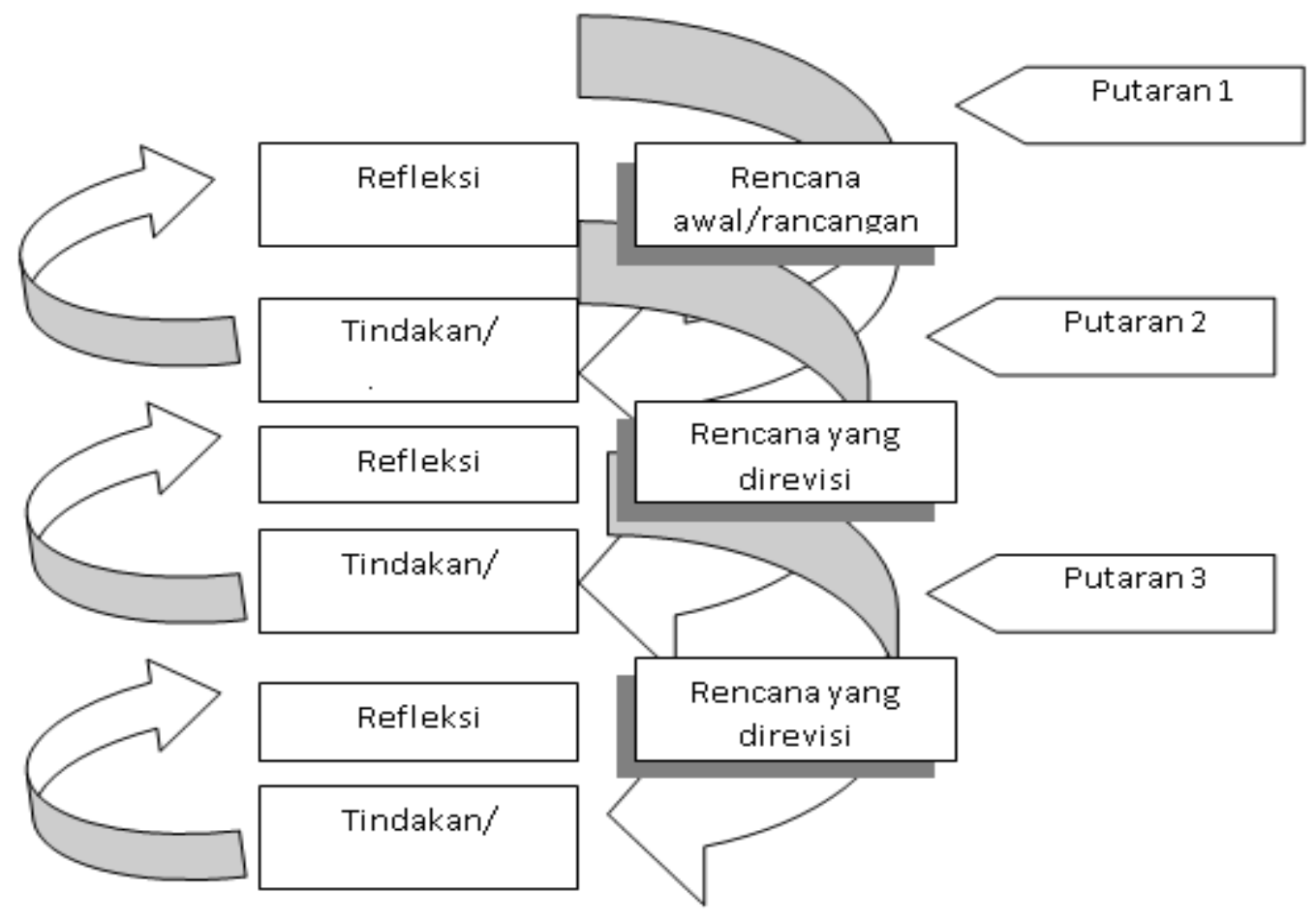

Gambar 1. Skema Penelitian Tindakan Kelas

Data-data yang diperlukan dalam penelitian ini diperoleh melalui observasi pengolahan belajar aktif, observasi aktivitas siswa dan guru, dan tes formatif.

Untuk mengetahui keefektivan suatu metode dalam kegiatan pembelajaran perlu diadakan analisa data. Pada penelitian ini menggunakan teknik analisis deskriptif kualitatif, yaitu suatu metode penelitian yang bersifat menggambarkan kenyataan atau fakta sesuai dengan data yang diperoleh dengan tujuan untuk mengetahui prestasi belajar yang dicapai siswa juga untuk memperoleh respon siswa terhadap kegiatan pembelajaran serta aktivitas siswa selama proses pembelajaran.

Untuk menganalisis tingkat keberhasilan atau persentase keberhasilan siswa setelah proses belajar mengajar setiap putarannya dilakukan dengan cara memberikan evaluasi berupa soal tes tertulis pada setiap akhir putaran.

Analisis ini dihitung dengan menggunakan statistik sederhana yaitu:

1. Untuk menilai ulangan atau tes formatif 
Peneliti melakukan penjumlahan nilai yang diperoleh siswa, yang selanjutnya dibagi dengan jumlah siswa yang ada di kelas tersebut sehingga diperoleh rata-rata tes formatif dapat dirumuskan:

$$
\bar{X}=\frac{\sum X}{\sum N}
$$

Dengan

$$
\begin{aligned}
: \bar{X} & =\text { Nilai rata-rata } \\
\Sigma \mathrm{X} & =\text { Jumlah semua nilai siswa } \\
\Sigma \mathrm{N} & =\text { Jumlah siswa }
\end{aligned}
$$

Ada dua kategori ketuntasan belajar yaitu secara perorangan dan secara klasikal. Berdasarkan petunjuk pelaksanaan belajar mengajar kurikulum 1994 (Depdikbud, 1994), yaitu seorang siswa telah tuntas belajar bila telah mencapai skor $65 \%$ atau nilai 65 , dan kelas disebut tuntas belajar bila di kelas tersebut terdapat $85 \%$ yang telah mencapai daya serap lebih dari atau sama dengan $65 \%$. Untuk menghitung persentase ketuntasan belajar digunakan rumus sebagai berikut:

$$
P=\frac{\sum \text { Siswa.yang.tuntas.belajar }}{\sum \text { Siswa }} \times 100 \%
$$

\section{HASIL DAN PEMBAHASAN}

Data penelitian yang diperoleh berupa hasil uji coba item butir soal, data observasi berupa pengamatan pengelolaan pembelajaran kooperatif model TGT dan pengamatan aktivitas siswa dan guru pada akhir pembelajaran, dan data tes formatif siswa pada setiap siklus. Data hasil uji coba item butir soal digunakan untuk mendapatkan tes yang betul-betul mewakili apa yang diinginkan. Data ini selanjutnya dianalisis tingkat validitas, reliabilitas, taraf kesukaran, dan daya pembeda.

Data lembar observasi diambil dari dua pengamatan yaitu data pengamatan pengelolaan pembelajaran kooperatif model TGT yang digunakan untuk mengetahui pengaruh penerapan model pembelajaran kooperatif model TGT dalam meningkatkan prestasi belajar siswa dan data pengamatan aktivitas siswa dan guru. Data tes formatif untuk mengetahui peningkatan prestasi belajar siswa setelah diterapkan pembelajaran kooperatif model TGT.

Sebelum melaksanakan pengambilan data melalui instrument penelitian berupa tes dan mendapatkan tes yang baik, maka data tes tersebut diuji dan dianalisis. Uji coba dilakukan pada siswa di luar sasaran penelitian. Analisis tes yang dilakukan meliputi:

1. Validitas

\begin{tabular}{|c|c|}
\hline Soal Valid & Soal Tidak Valid \\
\hline $\begin{array}{l}1,2,3,4,7,9,10,11,12,13,14,17 \\
19,21,23,25,26,27,28,29,30,36, \\
37,38,39,41,42,43,44,45\end{array}$ & $\begin{array}{l}5,6,8,15,16,18,20,22,24,31,32, \\
33,34,35,40,46\end{array}$ \\
\hline
\end{tabular}

Validitas butir soal dimaksudkan untuk mengetahui kelayakan tes sehingga dapat digunakan sebagai instrument dalam penelitian ini. Dari perhitungan 46 soal diperoleh 16 soal tidak valid dan 30 soal valid. Hasil dari validits soal-soal dirangkum dalam tabel di bawah ini.

Tabel 1. Soal Valid dan Tidak Valid Tes Formatif Siswa

\section{Reliabilitas}

Soal-soal yang telah memenuhi syarat validitas diuji reliabilitasnya. Dari hasil perhitungan diperoleh koefisien reliabilitas $r_{11}$ sebesar 0,554 . Harga ini lebih besar dari harga $r$ product moment. Untuk jumlah siswa $(\mathrm{N}=28)$ dengan $\mathrm{r}(95 \%)=0,374$. Dengan demikian soal-soal tes yang digunakan telah memenuhi syarat reliabilitas.

3. Taraf Kesukaran (P)

Taraf kesukaran digunakan untuk mengetahui tingkat kesukaran soal. Hasil analisis menunjukkan dari 46 soal yang diuji terdapat: 
- 20 soal mudah

- 15 soal sedang

- 11 soal sukar

4. Daya Pembeda

Analisis daya pembeda dilakukan untuk mengetahui kemampuan soal dalam membedakan siswa yang berkemampuan tinggi dengan siswa yang berkemampuan rendah.

Dari hasil analisis daya pembeda diperoleh soal yang berkteriteria jelek sebanyak 16 soal, berkriteria cukup 20 soal, berkriteria baik 10 soal. Dengan demikian soal-soal tes yang digunakan telah memenuhi syara-syarat validitas, reliabilitas, taraf kesukaran, dan daya pembeda.

\section{Analisis Data Penelitian Persiklus}

1. Siklus I

a. Tahap Perencanaan

Pada tahap ini peneliti mempersiapkan perangkat pembelajaran yang terdiri dari rencana pelajaran 1, soal tes formatif 1 dan alat-alat pengajaran yang mendukung.

b. Tahap Kegiatan dan Pelaksanaan

Pelaksanaan kegiatan belajar mengajar untuk siklus I dilaksanakan pada tanggal 04 November 2020 di Kelas IX H SMPN 1 Plered - Purwaakarta dengan jumlah siswa 28 siswa. Dalam hal ini peneliti bertindak sebagai guru. Adapun proses belajar mengajar mengacu pada rencana pelajaran yang telah dipersiapkan. Pengamatan (observasi) dilaksanakan bersamaan dengan pelaksaaan belajar mengajar

Pada akhir proses belajar mengajar siswa diberi tes formatif I dengan tujuan untuk mengetahui tingkat keberhasilan siswa dalam proses belajar mengajar yang telah dilakukan. Adapun data hasil penelitian pada siklus I adalah sebagai berikut:

Tabel 2 Nilai Tes Formatif Pada Siklus I

\begin{tabular}{|c|c|c|c|c|c|c|c|}
\hline \multirow{2}{*}{$\begin{array}{l}\text { No. } \\
\text { Urut }\end{array}$} & \multirow{2}{*}{ Nilai } & \multicolumn{2}{|c|}{ Keterangan } & \multirow{2}{*}{ No. Urut } & \multirow{2}{*}{ Nilai } & \multicolumn{2}{|c|}{ Keterangan } \\
\hline & & $\mathrm{T}$ & $\mathrm{TT}$ & & & $\mathrm{T}$ & TT \\
\hline 1 & 60 & & $\sqrt{ }$ & 15 & 60 & & $\sqrt{ }$ \\
\hline 2 & 50 & & $\sqrt{ }$ & 16 & 70 & $\sqrt{ }$ & \\
\hline 3 & 80 & $\sqrt{ }$ & & 17 & 70 & $\sqrt{ }$ & \\
\hline 4 & 70 & $\sqrt{ }$ & & 18 & 80 & $\sqrt{ }$ & \\
\hline 5 & 60 & & $\sqrt{ }$ & 19 & 70 & $\sqrt{ }$ & \\
\hline 6 & 80 & $\sqrt{ }$ & & 20 & 50 & & $\sqrt{ }$ \\
\hline 7 & 50 & & $\sqrt{ }$ & 21 & 70 & $\sqrt{ }$ & \\
\hline 8 & 70 & $\sqrt{ }$ & & 22 & 70 & $\sqrt{ }$ & \\
\hline 9 & 80 & $\sqrt{ }$ & & 23 & 60 & & $\sqrt{ }$ \\
\hline 10 & 50 & & $\sqrt{ }$ & 24 & 80 & $\sqrt{ }$ & \\
\hline 11 & 60 & & $\sqrt{ }$ & 25 & 70 & $\sqrt{ }$ & \\
\hline 12 & 60 & & $\sqrt{ }$ & 26 & 60 & & $\sqrt{ }$ \\
\hline 13 & 80 & $\sqrt{ }$ & & 27 & 70 & $\sqrt{ }$ & \\
\hline 14 & 70 & $\sqrt{ }$ & & 28 & 80 & $\sqrt{ }$ & \\
\hline Jumlah & 920 & 7 & 7 & Jumlah & 960 & 10 & 4 \\
\hline $\begin{array}{l}\text { Jumlah } \\
\text { Jumlah } \\
\text { Rata-Ra }\end{array}$ & $\begin{array}{l}\text { kor M } \\
\text { kor Te } \\
\text { a Skor }\end{array}$ & $\begin{array}{l}\text { al I } \\
18\end{array}$ & 800 & & & & \\
\hline
\end{tabular}

Keterangan:

$\mathrm{T}$

TT

Jumlah siswa yang tuntas

Jumlah siswa yang belum tuntas
: Tuntas

: Tidak Tuntas

: 17

: 11 
Tabel 3 Rekapitulasi Hasil Tes Formatif Siswa Pada Siklus I

\begin{tabular}{|l|l|l|}
\hline No & Uraian & Hasil Siklus I \\
\hline 1 & Nilai rata-rata tes formatif & 67,14 \\
2 & Jumlah siswa yang tuntas belajar & 17 \\
3 & Persentase ketuntasan belajar & 60,71 \\
\hline
\end{tabular}

Dari tabel di atas dapat dijelaskan bahwa dengan menerapkan pembelajaran kooperatif model TGT diperoleh nilai rata-rata prestasi belajar siswa adalah 67,14 dan ketuntasan belajar mencapai 60,71\% atau ada 17 siswa dari 28 siswa sudah tuntas belajar. Hasil tersebut menunjukkan bahwa pada siklus pertama secara klasikal siswa belum tuntas belajar, karena siswa yang memperoleh nilai $\geq 65$ hanya sebesar $60,71 \%$ lebih kecil dari persentase ketuntasan yang dikehendaki yaitu sebesar $85 \%$. Hal ini disebabkan karena siswa masih baru dan asing terhadap metode baru yang diterapkan dalam proses belajar mengajar.

\section{Siklus II}

Pelaksanaan kegiatan belajar mengajar untuk siklus II dilaksanakan pada tanggal 11 November 2020 di Kelas IX H SMPN 1 Plered - Purwakarta dengan jumlah siswa 28 siswa. Dalam hal ini peneliti bertindak sebagai guru. Adapun proses belajar mengajar mengacu pada rencana pelajaran dengan memperhatikan revisi pada siklus I, sehingga kesalah atau kekurangan pada siklus I tidak terulang lagi pada siklus II. Pengamatan (observasi) dilaksanakan bersamaan dengan pelaksanaan belajar mengajar.

Pada akhir proses belajar mengajar siswa diberi tes formatif II dengan tujuan untuk mengetahui tingkat keberhasilan siswa dalam proses belajar mengajar yang telah dilakukan. Instrument yang digunakan adalah tes formatif II. Adapun data hasil penelitian pada siklus II adalah sebagai berikut.

Tabel 4 Nilai Tes Formatif Pada Siklus II

\begin{tabular}{|c|c|c|c|c|c|c|c|}
\hline \multirow{2}{*}{$\begin{array}{l}\text { No. } \\
\text { Urut }\end{array}$} & \multirow{2}{*}{ Nilai } & \multicolumn{2}{|c|}{ Keterangan } & \multirow{2}{*}{ No. Urut } & \multirow{2}{*}{ Nilai } & \multicolumn{2}{|c|}{ Keterangan } \\
\hline & & $\mathrm{T}$ & $\mathrm{TT}$ & & & $\mathrm{T}$ & TT \\
\hline 1 & 80 & $\sqrt{ }$ & & 15 & 70 & $\sqrt{ }$ & \\
\hline 2 & 70 & & $\sqrt{ }$ & 16 & 60 & & $\sqrt{ }$ \\
\hline 3 & 90 & $\sqrt{ }$ & & 17 & 80 & $\sqrt{ }$ & \\
\hline 4 & 50 & $\sqrt{ }$ & & 18 & 70 & $\sqrt{ }$ & \\
\hline 5 & 70 & $\sqrt{ }$ & & 19 & 70 & $\sqrt{ }$ & \\
\hline 6 & 70 & & $\sqrt{ }$ & 20 & 70 & $\sqrt{ }$ & \\
\hline 7 & 70 & $\sqrt{ }$ & & 21 & 60 & & $\sqrt{ }$ \\
\hline 8 & 60 & & $\sqrt{ }$ & 22 & 90 & $\sqrt{ }$ & \\
\hline 9 & 70 & $\sqrt{ }$ & & 23 & 80 & $\sqrt{ }$ & \\
\hline 10 & 80 & $\sqrt{ }$ & & 24 & 60 & & $\sqrt{ }$ \\
\hline 11 & 80 & $\sqrt{ }$ & & 25 & 80 & $\sqrt{ }$ & \\
\hline 12 & 70 & $\sqrt{ }$ & & 26 & 60 & & $\sqrt{ }$ \\
\hline 13 & 70 & $\sqrt{ }$ & & 27 & 90 & $\sqrt{ }$ & \\
\hline 14 & 70 & $\sqrt{ }$ & & 28 & 70 & $\sqrt{ }$ & \\
\hline Jumlah & 1000 & 11 & 3 & Jumlah & 1010 & 10 & 4 \\
\hline $\begin{array}{l}\text { Jumlah } \\
\text { Jumlah } \\
\text { Rata-Ra }\end{array}$ & $\begin{array}{l}\text { kor } \mathrm{M} \\
\text { kor Te } \\
\text { a Skor }\end{array}$ & $\begin{array}{l}\text { al Ic } \\
20 \\
\text { pai } \\
\end{array}$ & 800 & & & & \\
\hline
\end{tabular}

Keterangan: 
TT

Jumlah siswa yang tuntas

: Tidak Tuntas

Jumlah siswa yang belum tuntas

Klasikal
$: 21$

$: 7$

: Belum tuntas

Tabel 5 Hasil Tes Formatif Siswa Pada Siklus II

\begin{tabular}{|l|l|l|}
\hline No & Uraian & Hasil Siklus II \\
\hline 1 & Nilai rata-rata tes formatif & 71,79 \\
2 & Jumlah siswa yang tuntas belajar & 21 \\
3 & Persentase ketuntasan belajar & 75,00 \\
\hline
\end{tabular}

Dari tabel di atas diperoleh nilai rata-rata prestasi belajar siswa adalah 71,79 dan ketuntasan belajar mencapai $75,00 \%$ atau ada 21 siswa dari 28 siswa sudah tuntas belajar. Hasil ini menunjukkan bahwa pada siklus II ini ketuntasan belajar secara klasikal telah mengalami peningkatan sedikit lebih baik dari siklus I. Adanya peningkatan hasil belajar siswa ini karena siswa mambantu siswa yang kurang mampu dalam mata pelajaran yang mereka pelajari. Disamping itu adanya kemampuan guru yang mulai meningkat dalam prose belajar mengajar.

c. Siklus III

Pelaksanaan kegiatan belajar mengajar untuk siklus III dilaksanakan pada tanggal 18 November 2020 di Kelas IX H SMPN 1 Plered dengan jumlah siswa 28 siswa. Dalam hal ini peneliti bertindak sebagai guru. Adapun proses belajar mengajar mengacu pada rencana pelajaran dengan memperhatikan revisi pada siklus II, sehingga kesalahan atau kekurangan pada siklus II tidak terulang lagi pada siklus III. Pengamatan (observasi) dilaksanakan bersamaan dengan pelaksanaan belajar mengajar.

Pada akhir proses belajar mengajar siswa diberi tes formatif III dengan tujuan untuk mengetahui tingkat keberhasilan siswa dalam proses belajar mengajar yang telah dilakukan. Instrumen yang digunakan adalah tes formatif III. Adapun data hasil penelitian pada siklus III adalah sebagai berikut:

Tabel 6 Nilai Tes Formatif Pada Siklus III

\begin{tabular}{|c|c|c|c|c|c|c|c|}
\hline \multirow{2}{*}{$\begin{array}{l}\text { No. } \\
\text { Urut }\end{array}$} & \multirow{2}{*}{ Nilai } & \multicolumn{2}{|c|}{ Keterangan } & \multirow{2}{*}{ No. Urut } & \multirow{2}{*}{ Nilai } & \multicolumn{2}{|c|}{ Keterangan } \\
\hline & & $\mathrm{T}$ & $\mathrm{TT}$ & & & $\mathrm{T}$ & TT \\
\hline 1 & 60 & & $\sqrt{ }$ & 15 & 80 & $\sqrt{ }$ & \\
\hline 2 & 80 & $\sqrt{ }$ & & 16 & 90 & $\sqrt{ }$ & \\
\hline 3 & 80 & $\sqrt{ }$ & & 17 & 80 & $\sqrt{ }$ & \\
\hline 4 & 70 & $\sqrt{ }$ & & 18 & 70 & $\sqrt{ }$ & \\
\hline 5 & 70 & $\sqrt{ }$ & & 19 & 80 & $\sqrt{ }$ & \\
\hline 6 & 90 & $\sqrt{ }$ & & 20 & 60 & & $\sqrt{ }$ \\
\hline 7 & 80 & $\sqrt{ }$ & & 21 & 80 & $\sqrt{ }$ & \\
\hline 8 & 60 & & $\sqrt{ }$ & 22 & 90 & $\sqrt{ }$ & \\
\hline 9 & 80 & $\sqrt{ }$ & & 23 & 80 & $\sqrt{ }$ & \\
\hline 10 & 90 & $\sqrt{ }$ & & 24 & 70 & $\sqrt{ }$ & \\
\hline 11 & 70 & $\sqrt{ }$ & & 25 & 80 & $\sqrt{ }$ & \\
\hline 12 & 80 & $\sqrt{ }$ & & 26 & 70 & $\sqrt{ }$ & \\
\hline 13 & 90 & $\sqrt{ }$ & & 27 & 70 & $\sqrt{ }$ & \\
\hline 14 & 70 & $\sqrt{ }$ & & 28 & 90 & $\sqrt{ }$ & \\
\hline Jumlah & 1070 & 12 & 2 & Jumlah & 1090 & 13 & 1 \\
\hline $\begin{array}{l}\text { Jumlah } \\
\text { Jumlah } \\
\text { Rata-Ra }\end{array}$ & $\begin{array}{l}\text { kor M } \\
\text { kor Te } \\
\text { a Skor }\end{array}$ & $\begin{array}{l}11 \mathrm{Id} \\
216\end{array}$ & 800 & & & & \\
\hline
\end{tabular}


Keterangan:

$\mathrm{T}$

TT

Jumlah siswa yang tuntas

Jumlah siswa yang belum tuntas

Klasikal

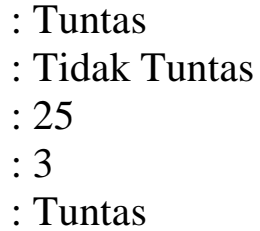

: Tuntas

: Tidak Tuntas

: Tuntas

Tabel 7 Hasil Tes Formatif Siswa Pada Siklus III

\begin{tabular}{|l|l|l|}
\hline No & Uraian & Hasil Siklus III \\
\hline 1 & Nilai rata-rata tes formatif & 77,14 \\
2 & Jumlah siswa yang tuntas belajar & 25 \\
3 & Persentase ketuntasan belajar & 89,29 \\
\hline
\end{tabular}

Berdasarkan tabel diatas diperoleh nilai rata-rata tes formatif sebesar 77,14 dan dari 28 siswa yang telah tuntas sebanyak 25 siswa dan 3 siswa belum mencapai ketuntasan belajar. Maka secara klasikal ketuntasan belajar yang telah tercapai sebesar 89,29\% (termasuk kategori tuntas). Hasil pada siklus III ini mengalami peningkatan lebih baik dari siklus II. Adanya peningkatan hasil belajar pada siklus III ini dipengaruhi oleh adanya peningkatan kemampuan siswa dalam mempelajari materi pelajaran yang telah diterapkan selama ini serta ada tanggung jawab kelompok dari siswa yang lebih mampu untuk mengajari temannya kurang mampu.

\section{Pembahasan}

Ketuntasan Hasil belajar siswa melalui hasil peneilitian ini menunjukkan bahwa pembelajaran kooperatif model TGT memiliki dampak positif dalam meningkatkan prestasi belajar siswa. Hal ini dapat dilihat dari semakin mantapnya pemahaman dan penguasaan siswa terhadap materi yang telah disampaikan guru selama ini (ketuntasan belajar meningkat dari sklus I, II, dan III) yaitu masing-masing 60,71\%, 75,00\%, dan 89,29\%. Pada siklus III ketuntasan belajar siswa secara klasikal telah tercapai.

Kemampuan Guru dalam Mengelola Pembelajaran Berdasarkan analisis data, diperoleh aktivitas siswa dalam proses pembelajaran kooperatif model TGT dalam setiap siklus mengalami peningkatan. Hal ini berdampak positif terhadap peningkatan prestasi belajar siswa dan penguasaan materi pelajaran yang telah diterima selama ini, yaitu dapat ditunjukkan dengan meningkatnya nilai rata-rata siswa pada setiap siklus yang terus mengalami peningkatan.

Aktivitas guru dan siswa dalam pembelajaran berdasarkan analisis data, diperoleh aktivitas siswa dalam proses pembelajaran Bahasa Indonesia dengan pembelajaran kooperatif model TGT yang paling dominan adalah, mendengarkan/memperhatikan penjelasan guru, dan diskusi antar siswa/antara siswa dengan guru. Jadi dapat dikatakan bahwa aktivitas isiwa dapat dikategorikan aktif. materi yang tidak dimengerti siswa, memberi umpan balik/evaluasi/tanya jawab dimana prosentase untuk aktivitas di dalam kelas. Sedangkan untuk aktivitas guru selama pembelajaran telah melaksanakan langkah-langkah pembelajaran kooperatif model TGT dengan baik. Hal ini terlihat dari aktivitas guru yang muncul di antaranya aktivitas membimbing dan mengamati siswa dalam mengerjakan kegiatan, menjelaskan atas cukup besar.

\section{KESIMPULAN}

Dari hasil kegiatan pembelajaran yang telah dilakukan selama tiga siklus, dan berdasarkan seluruh pembahasan serta analisis yang telah dilakukan dapat disimpulkan bahwa pembelajaran kooperatif model TGT memiliki dampak positif dalam meningkatkan prestasi belajar siswa yang ditandai dengan peningkatan ketuntasan belajar siswa dalam setiap siklus, yaitu siklus I $(60,71 \%)$, siklus II $(75,00 \%)$, siklus III $(89,29 \%)$. Penerapan pembelajaran kooperatif model TGT mempunyai pengaruh positif, yaitu dapat meningkatkan motivasi belajar siswa dalam belajar Bahasa Indonesia, hal ini ditunjukan dengan antusias siswa yang menyatakan bahwa siswa tertarik dan berminat dengan pembelajaran kooperatif model TGT 
sehingga mereka menjadi termotivasi untuk belajar. Pembelajaran kooperatif model TGT memiliki dampak positif terhadap kerjasama antara siswa, hal ini ditunjukkan adanya tanggung jawab dalam kelompok dimana siswa yang lebih mampu mengajari temannya yang kurang mampu.

\section{DAFTAR PUSTAKA}

A. M. (2000). Penelitian Tindakan Kelas. Makalah Penelitan Penulisan Karya Ilmiah Untuk Guru-guru Se-Kabupaten Tuban.

Ali, M. (1996). Guru Dalam Proses Belajar Mengajar. Bandung: Sinar Baru Algesindon.

AM., S. (1996). Interaksi dan Motivasi Belajar Mengajar. Jakarta: PAUPPAI Universitas Terbuka.

Arikunto, S. (1989). Penilaian Program Pendidikan. Proyek Pengembangan LPTK Depdikbud. Dirjen Dikti.

Arikunto, S. (1993). Manajemen Mengajar Secara Manusiawi. Jakarta: Rineksa Cipta.

Arikunto, S. (1999). Prosedur Penelitan Suatu Pendekatan Praktek. Jakarta: Rineksa Cipta.

Arikunto, S. (1999). Prosedur Penelitian Suatu Pendekatan Praktek. Jakarta: Rineksa Cipta.

Arikunto, S. (2001). Dasar-dasar Evaluasi Pendidikan. Jakarta: Bumi Aksara.

B., S. (1997). Proses Belajar Mengajar di Sekolah. Jakarta: PT. Rineksa Cipta.

Burton, W. H. (1986). Teknik-teknik Belajar dan Mengajar (Terjemahan). Bandung: Jemmars.

Dayan, A. (1972). Pengantar Metode Statistik Deskriptif. Lembaga Penelitan Pendidikan dan Penerangan Ekonomi.

Djamarah, S. B. (2002). Psikologi Belajar. Jakarta: Rineksa Cipta.

Djamarah, S. B. (2002). Strategi Belajar Mengajar. Jakarta: Rineksa Cipta.

Foster, B. (2002). Seribu Pena SLTP Kelas 1. Jakarta: Erlangga.

Hadi, S. (1981). Metotologi Research. Yogyakarta: Yayasan Penerbitan Fakultas Psikologi Universitas Gajah Mada.

Hamalik, O. (1992). Psikologi Belajar dan Mengajar. Bandung: Sinar Baru.

Hamalik, O. (1999). Kurikulum dan Pembelajaran. Jakarta: Bumi Aksara.

Margono. (1997). Metodologi Penelitian Pendidikan. Jakarta: Rineksa Cipta.

Moerdjiono, H. J. (1998). Proses Belajar Mengajar. Bandung: Remaja Rosdakarya.

Mursell, J. (t.thn.). Succesfull Teaching (Terjemahan). Bandung: Jemmars.

Naglim, P. M. (1990). Psikologi Pendidikan. Bandung: PT. Remaja Rosdakarya.

NK., R. (1991). Strategi Belajar Mengajar. Jakarta: Bina Aksara.

Nur, M. (2001). Pemotivasian Siswa Untuk Belajar. Surabaya: University Press. Universitas Negeri Surabaya.

Poerwodarminto. (1991). Kamus Umum Bahasa Indonesia. Jakarta: Bina Ilmu.

Slameto. (1988). Evaluasi Pendidikan. Jakarta: Bina Aksara.

Soekamto, T. (1997). Teori Belajar dan Model Pembelajaran. Jakarta: PAUPPAI, Universitas Terbuka.

Suryabrata, S. (1990). Psikologi Pendidikan. Yogyakarta: Andi Offset.

Syah, M. (1995). Psikologi Pendidikan, Suatu Pendekatan Baru. Bandung: Remaja Rosdakarya.

Usman, M. U. (2001). Menjadi Guru Profesional. Bandung: Remaja Rosdakarya.

W., A. C. (1984). The Profesional Edukation Of Teacher. Boston: Alin and Bacon. 